for all time a standard work on the subject of East African big game. The volume contains an introduction by Sir Sidney Harmer, and in addition to the chapters on elephants, giraffes, rhinoceroses, buffaloes and hippopotamuses, also has an interesting appendix on the ancestry of the African elephant, and the relationship of primitive elephants to primitive man. The volume concludes with a chapter on some of Maxwell's experiences in hunting elephants in India. This édition de luxe was followed a year later by a somewhat smaller and cheaper volume containing the same text and illustrations.

Always seeking after new experiences, in 1925 Marius Maxwell visited the Birunga Mountains north-east of Lake Kivu, in the Eastern Belgian Congo, to study and photograph the Eastern gorilla. He was accompanied by Mr. J. H. Barnes, the wellknown white hunter, who had been with him on his two previous trips in Kenya Colony. Although not having very great luck in photographing the gorilla itself, he took some very interesting photographs of the gorilla forests, of their sleeping platforms and of gorilla shelters. Further, he secured a unique snapshot of a female gorilla carrying on her back a young one; this, I think, is the only pictorial record of this method of juvenile transport in this species.

Maxwell had graduated at Zurich and took up the profession of engineering, specializing in the machinery concerned with the manufacture of canesugar, and he erected many sugar factories in India. Latterly, he had interested himself in coffee-farming, and lived on a large estate at Thika Bridge in Kenya Colony. He married in 1929 Miss Winifred Ramsay.

Guy Dollman.

\section{Lieut.-Colonel Robert Knowles, C.I.E.}

Ix is no exaggeration to say that tropical medicine has sustained a grievous loss through the early decease, on August 3 at fifty-two years of age, of Robert Knowles after a brave struggle with prolonged ill-health, aggravated by exceptionally hard work which a keen sense of duty would not allow him to relax.

After completing his medical studies at Cambridge and St. Mary's Hospital, Knowles took the first place at his entrance into the Indian Medical Service in 1908 in its palmiest days, and, after some years in military employ, obtained his first opportunities for research under favourable conditions at the Kasauli Institute. Here he began a happy and successful collaboration with his friend, H. W. Acton, and they made important contributions on the subject of snake venoms. Here he also commenced his fruitful work on protozoology in connexion with the halteridium. After the interruption caused by the Great War, when he was severely wounded in Mesopotamia, he took charge of the recently founded Pasteur Research Institute in the beautiful hill station of Assam at Shillong, where his energies and organizing ability found ample scope, and where he commenced his important investigations on kalaazar.
When Sir Leonard Rogers had to return home a few months before he had completed the organization of the Calcutta School of Tropical Medicine, he asked that Knowles should succeed him, and once more he was an outstanding success, and soon became professor of protozoology, with his friend Acton as professor of bacteriology, and during the next sixteen years his work there can only be described as most remarkable. His most outstanding discovery was the demonstration, with the aid of L. E. Napier and R. O. A. Smith, that the sand-fly, Phlebotomus argentipes, was the long sought-for carrier of the infection of kala-azar. Later he did valuable work on a parasite of monkey malaria called Plasmodium knoulesi after him.

Knowles was equally distinguished for his medicoliterary work, and was a clear and prolific writer, his work on medical protozoology being of exceptional merit, and those with Acton on the dysenteries of India, and with S. White on malarial literature in India were of great value. First as assistant editor with Sir John Megaw, and later as editor of the Indian Medical Gazette, he raised its standard and contributed invaluable summaries of the advances during each year, at the compilation of which he was a master.

Knowles's short, thickset figure, abounding in energy and enthusiasm, combined with the unselfish and cheerful manner in which he always found time to help any of his colleagues, British or Indian, makes his early loss quite irreparable to his innumerable friends.

\section{Dr. W. F. Sheppard}

Dr. W. F. ShEPpard, late assistant secretary, Board of Education, died on October 12 in his seventy-third year. He went up to Trinity College, Cambridge, was Senior Wrangler in 1884 (Parts I and II) and was placed in Division I of Part III in 1885 . He was elected a fellow of Trinity in 1887. For these particulars we are indebted to the obituary in The Times.

The name of Sheppard is well known to mathematical statisticians. In 1898 he published in the Phil. Trans. (A, 192, 101) a memoir "On the Application of the Theory of Error to Cases of Normal Distribution and Normal Correlation", in which the theory is developed by very elegant geometrical methods. It was in this memoir that he gave the noteworthy theorem, that if a fourfold table is formed from a normal correlation table by division at the medians, the coefficient of correlation $r$ is given by

$$
r=\cos \left(1-\frac{2 n}{N}\right) \pi,
$$

where $n$ is the frequency in either of the positive quadrants.

Much of Dr. Sheppard's work, in the Proceedings of the London Mathematical Society and elsewhere, was concerned with the method of finite differences and its applications. By this method he derived the wellknown 'Sheppard's corrections' for determining 